\title{
A Review on Nipah Virus (NiV) for Healthcare Professionals
}

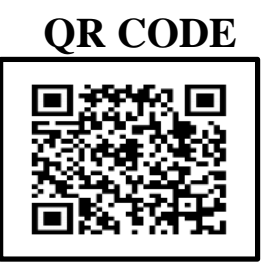

\section{MEENA PARASHAR}

The periodic occurrence of the Nipah Virus (NiV) infection predominantly in the south-east Asian region leads to high mortality rates among those affected. Primarily considered to be a zoonotic disease, this disease can also spread from human contact and through infected sources, especially food. Since there is no specific line of treatment for this deadly disease as no specific antiviral is present for this disease, the need for an immediate symptomatic relief increases the chances of survival in an individual. It is important that doctors and healthcare professionals update their knowledge and maintain their high standards of infection control to prevent the risk of patient-doctor transmission. This review in general provides valuable data on various aspects of the $\mathrm{NiV}$ infection for those in healthcare settings.

KEYWORDS: Nipah, Virus, Nosocomial, Bats, Mortality

\section{INTRODUCTION}

A zoonotic virus with periodic outbreaks occurring predominantly in the south-east Asian region, the Nipah virus (NiV) can also be transmitted through contaminated food or directly between humans. Persons infected with this illness, are seen with a range of symptoms and disease which include asymptomatic (subclinical) infection to acute respiratory illness and encephalitis which is fatal in nature. $^{1}$

A paramyxovirus related to Hendra virus, the first documented case of Nipah Virus emerged in Malaysia in 1998, and the outbreak also affected Singapore. The virus has been reported to reappear on many different occasions and causes severe infections that is associated with high mortality rates among the affected people. ${ }^{2}$ The only method to address this highly fatal and contagious disease is to provide symptomatic treatment to the affected people promptly. ${ }^{3}$

The incidence of Nipah virus was observed in Bangladesh in the year 2001, and since then, nearly annual outbreaks been occurring in the country. Periodical occourence of this disease has been identified in two Indian states till now: West Bengal (2001, 2007) and Kerala (2018, 2019).

In its first occurrence in West Bengal in the year 2001, a total of 66 cases and 45 mortalities due to Nipah virus were reported. In the southern state of Kerela, in the year 2018, 17 deaths were seen from a total of the 19 reported cases from Kozhikode and Malappuram. ${ }^{4}$

Owing to the high fatality rates of the viral infection, this review was written with the aim to provide the scientific community with a brief knowledge regarding the Nipah virus and its characteristics.

\section{THE NIPAH VIRUS}

The $\mathrm{NiV}$ is placed along with $\mathrm{HeV}$ in the genus Henipavirus of family Paramyxoviridae as it showed $68 \%$ to $92 \%$ and $40 \%$ to $67 \%$ homology with $\mathrm{HeV}$ in protein-coded regions and non-translated regions. Variations in the strain has been observed between human NiV isolates collected from the outbreaks in Malaysia, India, and Bangladesh. ${ }^{5}$

Although the virus predominantly spreads from animals to humans, one of the clearest illustrations of person-to-person transmission of $\mathrm{NiV}$ occurred during the Faridpur outbreak (2004), in which, the chain of infections transmission eventually involved 5 generations and affected a total of 34 people. ${ }^{6}$

\section{ETIOLOGY}

The natural reservoir for Nipah virus and related members of the genus Henipavirus are fruit bats of the genus Pteropus. ${ }^{7}$ However, both Hendra and Nipah viruses possess an exceptionally broad species tropism and both natural and experimental infections 
of these two viruses have demonstrated their capacity to cause disease as is often fatal in horses, pigs, cats, dogs, ferrets, hamsters, guinea pigs, monkeys, and humans etc. Nipah virus and Hendra virus cause a systemic infection that is characterized as a widespread vasculitis and endothelial cell tropism. ${ }^{8}$

\section{CLINICAL SIGNS AND SYMPTOMS}

Clinical symptoms of $\mathrm{NiV}$ infection are broad, ranging from the asymptomatic to very severe. ${ }^{7}$ The incubation period (in human beings) ranged from a period of 4 days to 2 months, with more than $90 \%$ of the infection seen at 2 weeks or lesser duration of time. $^{8}$

Affected patients presented with symptoms like fever, headache, dizziness, and vomiting, which developed into a clinical picture of severe encephalitis. Reduced level of consciousness and prominent signs of brainstem dysfunction, including abnormal doll's eye reflex, pupillary reflexes, vasomotor changes, seizures, and myoclonic jerks were seen in many patients.9 The neurological involvement was diverse and multifocal, including aseptic meningitis, diffuse encephalitis, and focal brainstem involvement. Cerebellar signs were relatively common.

Certain neurological signs such as behavioural changes, spasms, uncoordinated gait and myoclonus were reported in patients from Bangladesh while cough was the comomonly presented respiratory symptom. Atypical pneumonia was reported in $14 \%$ cases in outbreak of this disease in Malaysia. ${ }^{10}$

\section{DIAGNOSIS}

Diagnosis of $\mathrm{NiV}$ is based on laboratory diagnostic tests which consists of detecting anti-NiV immunoglobulin $\mathrm{M}$ (IgM) and IgG antibody in the serum and cerebrospinal fluid (CSF).

The most commonly used diagnostic method is the ELISA test, using monoclonal antibody-based antigen, for virus detection and for differentiating $\mathrm{NiV}$ from Hendra virus.11 Other methods available include the serum neutralizing tests, RT-PCR for detection of viral RNA from serum, urine, and CSF, virus isolation and nucleic acid amplification test.12 Magnetic resonance imaging (MRI) of the brain serves as a sensitive diagnostic tool in acute and relapse/late-onset $\mathrm{NiV}$ encephalitis, when the diagnostic sensitivity of ELISA is not reliable. ${ }^{12}$

\section{PREVENTIVE STRATEGIES ${ }^{13}$}

The various preventive strategies can be incorporated to prevent $\mathrm{NiV}$ transmission are as follows:

1. Transmission of virus from patient to his/her attendant can be significantly reduced through frequent hand washing, avoiding sharing of food and/or bed with the affected person.

2. Using gloves and masks while handling of infected body of the deceased person is an absolute measure that needs to be undertaken to avoid corpse to human transmission. In circumstances where the availibity of gloves and masks is limited, thorough hand washing with soap and water immediately is advised to prevent disease transmission.

3. Nosocomial transmission can be minimized by ensuring proper hand washing facilities, through the use of personal protective equipment (PPE) and isolation of the meningoencephalitis patients during NiV outbreaks.

4. Proper care while washing and/or peeling of fruits followed by adoption of proper hand hygiene practices during meals.

5. Use of various communication strategies like local television or radio channels and print media to be used to create awareness among people regarding the spread of this deadly virus.

6. Implementing the Bamboo skirt method (to prevent contaminating the date palm sap) and sap branch method ( the shaved part of the tree is covered with its own branches, cloth or mosquito net) should be adopted to prevent infestation of fruits and other tree products from getting infected. ${ }^{14}$

\section{TREATMENT}

The treatment for $\mathrm{NiV}$ is supportive care only as no antiviral specifically available to treat this disease has been made available till date. The antivirals ribavirin (Malaysian outbreak) and acyclovir (Singapore outbreak) have been used and they have significantly reduced the mortality rates of this deadly disease.

\section{CONCLUSION}

Keeping in mind the high fatality in the case of $\mathrm{NiV}$ infection, doctors and health professionals are advised to keep themselves updated regarding this disease, use personal protective equipment (PPEs) adequately to prevent the chances of transmission in them and initiate immediate treatment for the ones suffering from this deadly disease, to lower the mortality risk among patients. 


\section{REFERENCES}

1. World Health Organisation (WHO) fact Sheet. Available from: https://www.who.int/news-room/factsheets/detail/nipah-virus [Last accessed on $19^{\text {th }}$ May, 2019]

2. Sharma V, Kaushik S, Kumar R, Yadav JP, Kaushik

S. Emerging trends of Nipah virus: A review. Rev Med Virol. 2019;29(1):e2010.

3. Treatment | Nipah Virus (NiV) | CDC. Available from:

https://www.cdc.gov/vhf/nipah/treatment/index.html. [Cited 21 March 2019].

4. https://www.newsi8.com/news/india/only-a-singlenon-fatal-case-of-nipah-virus-reported-from-keralathis-year-says-union-health-minister-2197995.html 5. Sharma V, Kaushik S, Kumar R, Yadav JP, Kaushik S. Emerging trends of Nipah virus: A review. Rev Med Virol. 2018;e2010.

6. Gurley ES, Montgomery JM, Hossain MJ, Bell M, Azad AK, Islam MR, et al. Person-to-person transmission of Nipah virus in a Bangladeshi community. Emerg Infect Dis 2007;13:1031-7.

7. Epstein JH, Field HE, Luby S, Pulliam JRC. Daszak P. Nipah virus: Impact, origins, and causes of emergence. Current Infectious Disease Reports 2006;8(1):59-65.
8. Geisbert TW, Feldmann H, Broder CC. Animal Challenge Models of Henipavirus Infection and Pathogenesis. Curr Top Microbiol Immunol. 2012;359:153-177.

9. World Health Organization. Emergencies preparedness, response. Nipah virus-India. 2018. http://www.who.int/csr/don/o7-august-2018-nipahvirus-india/en/. Accessed May 10, 2019.

10. Satterfield BA, Dawes BE, Milligan GN. Status of vaccine research and development of vaccines for Nipah virus. Vaccine 2016;34:26:2971-5.

11. Kulkarni DD, Tosh C, Venkatesh G, Kumar DS. Nipah virus infection: current scenario. Indian J Virol, 2013;24 (3):398-408.

12. Abdullah S, Tan CT. Henipavirus encephalitis. Handb Clin Neurol. 2014;123:663-70.

13. Ambat AS, Zubair SM, Prasad N, Pundir P, Rajwar E, Patil DS, et al. Nipah virus: A review on epidemiological characteristics and outbreaks to inform public health decision making. Journal of Infection and Public Health. [Article in Press] Available Online from: https://www.sciencedirect.com/science/article/pii/S18 7603411930084X\#biboozo

14. Dhillon J, Banerjee A. Controlling Nipah virus encephalitis in Bangladesh: policy options. J Public Health Policy 2015; 36(3): 270-82.

Source of support: Nil, Conflict of interest: None declared 